\title{
Economic Analysis of Barley Production under Solar Irrigation System in Jaipur, Rajasthan
}

\author{
Yash Gautam*, O. P. Singh and P. K. Singh \\ Department of Agricultural Economics, Institute of Agricultural Sciences, \\ BHU, Varanasi, India \\ *Corresponding author
}

\section{A B S T R A C T}

\section{Keywords}

Bajra, Solar irrigation system, CACP Cost concept, Cobb Douglas, Resource use efficiency

\section{Article Info}

Accepted:

12 December 2020 Available Online: 10 January 2021
Barley is globally one of the most important cereal grain crops after rice, wheat and maize. It is a short growing season crop and is highly drought tolerant. Earlier, barley was mainly used as livestock feed but now it is one of the grains used daily in human consumption. Rajasthan is among the largest coarse cereal producing states. India relies mainly on fossil fuels to meet its energy requirements. Currently India is the third largest Greenhouse gas emitter in the world after China and USA. Today, the results of climate change are clearly visible and they are going to worsen further if initiatives are not taken. In order to reduce the greenhouse gas emissions and reduce climate change problem, government took several initiatives that promote adoption of green energy. Various schemes like Jawaharlal Nehru National Solar Mission, KUSUM scheme etc are few steps taken in the direction of sustainable development. Under these schemes, government provides subsidies and financial support to the farmers for setting up solar irrigation pumps on their field and barren lands. Crop production under solar irrigation system provides higher income as compared to the crop production under diesel irrigation system. It is because the irrigation charges or diesel charges in diesel irrigation system are saved in solar irrigation system. Hence, this study was performed to analyse the economics of bajra cultivation under solar irrigation system.

\section{Introduction}

Barley is globally one of the most important cereal grain crops after rice, wheat and maize. In India, it is cultivated during summer in temperate regions and in winter in tropical regions. It is a short growing season crop and is highly drought tolerant. Earlier, barley was mainly used as livestock feed but now it is one of the grains used daily in human consumption. Barley also play important role in industrial consumption. Coarse cereals are made out of this along with other cereal crops like oats, bajra, finger millet, maize and sorghum. Generally, Barley is cultivated as rabi season crop in India and sowing is done from October to December while it is harvested from March to May. It is commonly grown in the states of Uttar Pradesh, Rajasthan, Madhya Pradesh, Bihar, Punjab and Haryana. Barley thrives well in marginal, saline or alkaline soils and in water scarce 
areas as rainfed crop. It is also cultivated for malting and brewing purposes in Haryana, Western U.P., Punjab and Rajasthan with relatively better management to get good grain quality.

Area under coarse cereal crops has reduced from 37.67 million hectares in 1950-51 to 24.15 million hectares in 2014-15. However, production has increased from 15.38 million tonnes to 41.75 million tonnes during the same period (GoI, 2020). Yield of barley increased from $1938 \mathrm{Kg} / \mathrm{Ha}$ in 2005-06 to $2881 \mathrm{Kg} / \mathrm{Ha}$ in 2018-19(DAC\&FW, 2019).

Rajasthan is among the largest coarse cereal producing states. Area under coarse cereals in 2014-15 was 6.26 million hectares producing to the tune of 6.43 million tonnes. Area under irrigation in 2012-13 was only 7.4 per cent of the total area under barley cultivation in Rajasthan (GoI, 2020).

In 2014, India had used approximately more than 4 billion litres of diesel and approximately 85 million tons of coal per annum to support water pumping for irrigation (KPMG, 2014). Generally, burning of one litre of diesel fuel produces $2.6 \mathrm{Kg}$ of carbon dioxide and from one kilogram of carbon dioxide, approximately, $0.27 \mathrm{~kg}$ of carbon is released. Considering the level of production of barley in India and the amount of diesel used for irrigation, it can be easily understood how much carbon emission is done.

India relies mainly on fossil fuels to meet its energy requirements. Approximately 69.5 per cent of the total power gets generated by thermal power plants (MoP, 2020). In India electricity generated by burning fossil fuels contributes 37.8 per cent of the total greenhouse gasses that is released in the atmosphere (GOI, 2016). Burning of fossil fuels increases carbon-dioxide emission which is a major contributor to the climate change crisis today (Schock et al., 2007). In 2016, World Health Organization stated in a report that, 11 Indian cities have occupied positions in the list of most polluted cities of the world (WHO, 2017).Currently, India is the third largest Greenhouse gas emitter in the world after China and USA. Today, the results of climate change are clearly visible and they are going to worsen further if initiatives are not taken.

Renewable energy sources are capable to solve the problem of sustainable development associated with fossil fuel based power plants as these energy sources are unlimited, ecofriendly and provides energy with negligible emissions of air pollutant and greenhouse gases (Singal, 2007). It is clearly feasible to replace the current fossil fuel infrastructure with solar power and other renewable, and reduce $\mathrm{CO} 2$ emissions to a level commensurate with the most aggressive climate change goal (Fthenakis et al., 2009).

Crop production under solar irrigation system provides higher income as compared to the crop production under diesel irrigation system. It is because the irrigation charges or diesel charges in diesel irrigation system are saved in solar irrigation system. Cost of cultivation of groundnut under solar irrigation system was Rs. 74,415.29 whereas the gross return obtained by farmer was Rs. $1,00,445.41$. Hence, the net income was Rs.30,350.31 (Gautam and Singh, 2020). Similarly, the net income of farmer who produced pearl millet under solar irrigation system was higher as compared to diesel irrigation system (Gautam and Singh, 2020).

In India, highest numbers of solar irrigation pumps are installed in Rajasthan, Punjab, Bihar and Haryana. Solar energy intensity varies geographically. Highest annual global radiation of $\geq 2400 \mathrm{kWh} / \mathrm{m} 2$ is received in 
Rajasthan and northern Gujarat. Rajasthan receives solar radiation of $6.0-7.0 \mathrm{kWh} / \mathrm{m} 2$. It receives low rainfall and about 325 days have good sunshine in a year. In western areas like Thar Desert it may extend up to 345-355 days as rains occur only for 10.4-20.5 days in a year (Meena et al., 2014).

In order to reduce the greenhouse gas emissions and reduce climate change problem, government took several initiatives that promote adoption of green energy. Various schemes like Jawaharlal Nehru National Solar Mission, KUSUM scheme etc are few steps taken in the direction of sustainable development. Under these schemes, government provides subsidies and financial support to the farmers for setting up solar irrigation pumps on their field and barren lands. Government is taking keen interest in solarising several community diesel pumps on a large scale. The government will provide incentive to DISCOMS for purchasing additional energy generated.

All these initiatives are taken to promote solar irrigation pumps over diesel irrigation pumps. Considering the importance of the barley crop and the amount of fuel it requires for irrigation, it is a necessary step to move towards solar irrigation pump. Hence, following study was undertaken to analyse the economic feasibility of barley production under solar irrigation pump system.

\section{Materials and Methods}

The study was based on primary data collected with the help of survey schedule. Rajasthan was purposively selected because it receives the highest annual global radiation and the installation of solar irrigation pumps are maximum. Jaipur was selected purposively because number of solar irrigation pumps installed were maximum in the district. Respondents were selected with snowball sampling method. Cost of cultivation and return were calculated using cost concept suggested by Commission for Agricultural Costs and Prices (Gautam and Singh, 2018). Cobb Douglas production function was used to analyse the resource use efficiency of the inputs included in the model.

Cost A1 = All actual expenses in cash and kind incurred in production by the owner.

Cost $\mathrm{A} 2=$ Cost $\mathrm{A} 1+$ rent paid for leased in land

Cost $\mathrm{B} 1=$ Cost $\mathrm{A} 1+$ interest on value of owned capital asset (excluding land)

Cost $\mathrm{B} 2=$ Cost $\mathrm{B} 1+$ rental value of owned land

Cost $\mathrm{C} 1=$ Cost $\mathrm{B} 1+$ imputed value of family labour.

Cost $\mathrm{C}_{2}=$ Cost $\mathrm{B} 2+$ imputed value of family labour

Cost $\mathrm{C}_{3}=\operatorname{Cost} \mathrm{C} 2+10 \%$ of $\mathrm{C}_{2}$

\section{Productivity of key input factors}

To work out the productivity, Cobb Douglas production function was used in following form:

$\mathrm{Y}=\mathrm{ax} \mathrm{x}_{1}^{\mathrm{b}_{1}} \mathrm{x}_{2}^{\mathrm{b}_{2}} \mathrm{x}_{3}^{\mathrm{b}_{\mathrm{a}}} \mathrm{x}_{4}^{\mathrm{b}_{4}} \mathrm{x}_{5}^{\mathrm{b}_{5}}$

Where,

$\mathrm{Y}=$ Gross return per hectare in Rs.

$\mathrm{a}=$ Constant

$\mathrm{x}_{1}=$ Human Labor use per hectare in Rs.

$\mathrm{x}_{2}=$ Machine use per hectare in Rs.

$\mathrm{x}_{3}=$ Seed per hectare in Rs.

$\mathrm{x}_{4}=$ Fertilizer use per hectare in Rs.

$\mathrm{X}_{5}=$ Irrigation per hectare in Rs.

$b_{1}, b_{2}, b_{3}, b_{4}$ and $b_{5}$ are the elasticities of production for inputs $\mathrm{x}_{1}, \mathrm{x}_{2}, \mathrm{x}_{3}, \mathrm{x}_{4}$ and $\mathrm{x}_{5}$ respectively. 


\section{Results and Discussion}

\section{Cost concept analysis}

Per hectare operational cost and fixed cost incurred in the cultivation of barley under solar irrigation system is presented in the Table 1. It was found that the average total cost of cultivation was ₹ $63,122.72$, out of which operational cost was ₹ 40,675.92 and fixed cost amounted to ₹ 16,708.37. The percentage contribution of operational cost in the total cost was 64.43 per cent and that a fixed cost was 26.46 per cent. Managerial cost was estimated to be ₹ 5,738.429.

Figure 1 shows the share of major inputs in the cost of cultivation of barley under solar irrigation system. It was observed that highest contribution in the total cost was of human labour (32 per cent), irrigation (13 per cent) and fertilizer ( 3 per cent), machine labour (10 per cent) seed (6 per cent). The fixed cost contributed to the extent of 26 per cent in the total cost.

Table.1 Item wise Breakup of Cost of Production (₹ per Ha.)

\begin{tabular}{|c|c|c|c|}
\hline & \multicolumn{2}{|c|}{ Costs } & Amount \\
\hline $\mathbf{A}$ & \multicolumn{2}{|l|}{ Operational Cost } & $40,675.92$ \\
\hline \multirow[t]{4}{*}{1} & \multirow[t]{4}{*}{ Human Labour } & Family & $17,862.15$ \\
\hline & & Attached & 0.00 \\
\hline & & Casual & $2,185.84$ \\
\hline & & Total & $20,047.99$ \\
\hline \multirow[t]{3}{*}{2} & \multirow[t]{3}{*}{ Animal Labour } & Hired & 0.00 \\
\hline & & Owned & 0.00 \\
\hline & & Total & 0.00 \\
\hline \multirow[t]{3}{*}{3} & \multirow[t]{3}{*}{ Machine Labour } & Hired & $3,025.71$ \\
\hline & & Owned & $3,036.24$ \\
\hline & & Total & $6,061.95$ \\
\hline 4 & \multicolumn{2}{|l|}{ Seed } & $3,456.96$ \\
\hline \multirow[t]{3}{*}{5} & \multirow[t]{3}{*}{ Fertilizer \& Manure } & Fertilizer & 2174.16 \\
\hline & & Manure & 0.00 \\
\hline & & Total & 2174.16 \\
\hline 6 & \multicolumn{2}{|l|}{ Insecticides } & 96.39 \\
\hline 7 & \multicolumn{2}{|l|}{ Irrigation Charges } & $8,485.64$ \\
\hline 8 & \multicolumn{2}{|c|}{ Miscellaneous } & 0.00 \\
\hline 9 & \multicolumn{2}{|c|}{ Interest on Working Capital } & 352.83 \\
\hline B & \multicolumn{2}{|c|}{ Fixed Costs } & $16,708.37$ \\
\hline 1 & \multicolumn{2}{|c|}{ Rental Value of Owned Land } & $12,816.76$ \\
\hline 2 & \multicolumn{2}{|c|}{ Rent Paid For Leased-in-Land } & 0.00 \\
\hline 3 & \multicolumn{2}{|c|}{ Land Revenue, Taxes, Cesses } & 17.67 \\
\hline 4 & \multicolumn{2}{|c|}{ Depreciation on Implements \& Farm Building } & $3,466.42$ \\
\hline 5 & \multicolumn{2}{|c|}{ Interest on Fixed Capital } & 407.52 \\
\hline $\mathrm{C}$ & \multicolumn{2}{|c|}{ Operational Cost + Fixed Cost $[\mathrm{A}+\mathrm{B}]$} & $57,384.29$ \\
\hline D & \multicolumn{2}{|c|}{ Managerial cost } & $5,738.429$ \\
\hline $\mathbf{F}$ & \multicolumn{2}{|l|}{ Total cost $[\mathrm{C}+\mathrm{D}]$} & $63,122.72$ \\
\hline
\end{tabular}


Table.2 Per hectare cost of cultivation of barley under solar irrigation system

\begin{tabular}{|c|l|c|}
\hline S. No. & Particulars & Amount (₹ ) \\
\hline $\mathbf{1}$ & Cost A1 & $26,297.87$ \\
\hline $\mathbf{2}$ & Cost A2 & $26,297.87$ \\
\hline $\mathbf{3}$ & Cost B1 & $26,705.39$ \\
\hline $\mathbf{4}$ & Cost B2 & $39,522.14$ \\
\hline $\mathbf{5}$ & Cost C1 & $44,567.54$ \\
\hline $\mathbf{6}$ & Cost C2 & $57,384.30$ \\
\hline $\mathbf{7}$ & Cost C3 & $63,122.726$ \\
\hline
\end{tabular}

Table.3 Per hectare returns of barley under solar irrigation system

\begin{tabular}{|l|l|r|}
\hline S. No. & \multicolumn{1}{|c|}{ Particulars } & Amount (₹) \\
\hline $\mathbf{1}$ & Main product & $57,095.95$ \\
\hline $\mathbf{2}$ & By product & $23,185.48$ \\
\hline $\mathbf{3}$ & Gross return & $80,281.43$ \\
\hline $\mathbf{4}$ & COC & $57,384.29$ \\
\hline $\mathbf{5}$ & Cost C3 & $63,122.72$ \\
\hline $\mathbf{6}$ & Net return & $17,158.71$ \\
\hline $\mathbf{7}$ & Net Income = Irrigation charges + Net return & $25,644.35$ \\
\hline
\end{tabular}

Table.4 Regression coefficients of variables included in the regression model

\begin{tabular}{|c|c|c|c|c|c|c|}
\hline Particulars & Intercept & $\begin{array}{l}\text { Human } \\
\text { Labour }\end{array}$ & $\begin{array}{l}\text { Machine } \\
\text { Labour }\end{array}$ & Seed & Fertilizer & Irrigation \\
\hline Coefficients & -0.4419 & -0.3877 & 1.4594 & -0.08 & 0.0025 & -0.0019 \\
\hline t Stat & & -18.2362 & 63.3137 & -5.4448 & 0.1302 & -0.1414 \\
\hline$P$ value & & $3.9 \mathrm{E}-22$ & $7.34 \mathrm{E}-45$ & $2.19 \mathrm{E}-06$ & 0.8969 & 0.8881 \\
\hline \multicolumn{4}{|c|}{$\sum \mathbf{b}_{\mathbf{i}}=\mathbf{0 . 9 8 8 4}$} & \multicolumn{3}{|c|}{$R^{2}=0.9980$} \\
\hline
\end{tabular}

Significant at 5 per cent level

Fig.1 Share of different factors in cost of cultivation of barley under solar irrigation system

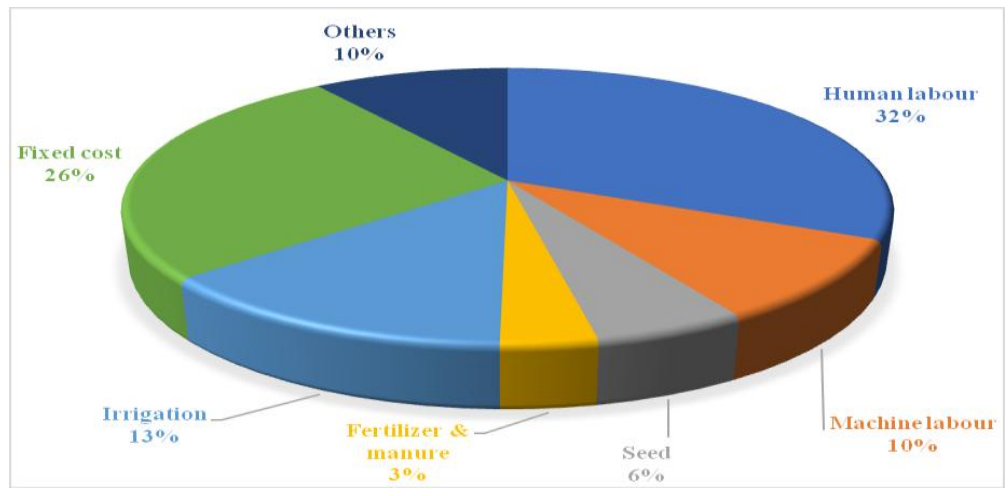


Cost of cultivation as suggested by cost concept Commission on Agricultural Cost and Prices (CACP) is shown in table 2. It can be observed it was observed that Cost A1 was₹ 26,297.87 and Cost A2 was 26,297.87in the study area. Cost B1, B2, C1, C2, C3 were estimated to be ₹ $26,705.39$, ₹ 39,522.14, ₹ 44,567.54, ₹ 57,384.30, and ₹ 63,122.726 respectively.

Table 3 shows the returns of barley under solar irrigation system. It was estimated that the return from main product and by product was equal to ₹ 57,095.95and ₹ 23,185.48respectively. The net return was₹ 17,158.71. Under solar irrigation system, farmer didn't have to pay any irrigation charge because farmer had installed solar pump on their farm and operation of solar pump doesn't require any additional input or charges.

Therefore the irrigation charges that farmer had to pay before the installation of solar pump were saved. Hence, that irrigation charge which was saved was considered to be the part of the income of the farmer. So, the net income of the farmer after including irrigation charges was estimated to be ₹ 25,644.35.

\section{Resource use efficiency}

The value of coefficient of multiple determination capital R square was 0.9980. It indicates that 99.80 per cent variation in logarithmic value of gross returns was explained by the independent variables (human labour, machine labour, seed, fertiliser and irrigation) included in the regression model.

The coefficient of elasticity of production of machine labour turned out to be positive and significant. It means that for every 1 per cent increase in machine labour there be an increase in the gross return by 1.4594 per cent keeping the other variable resources considered in the equation constant at their geometric mean level.

The coefficient of elasticity of production of human labour turned out to be negative and significant. It means that for every 1 per cent increase in human labour there be decrease in the gross return by 0.3877 per cent keeping the other variable resources considered in the equation constant at their geometric mean level. Similarly, coefficient of elasticity of production of seed was found to be negative and significant.

Coefficient of elasticity of production of fertilizer was found to be positive and insignificant while it was negative and insignificant in case of irrigation. Since the elasticity of coefficient was statistically insignificant so it means that no impact of fertilizer and irrigation was visible on the gross returns.

The sum of the regression coefficients of variables was more than one i.e. $\sum b_{i}=0.9884$ which meant that there was decreasing returns to scale. It implies that with the increase in input the output is increasing but with decreasing rate. It may be because of the operation of diseconomies of scale.

Also, some inputs were not used optimally. If the inputs which were positive and significant like fertilizer and seed were used increasingly and optimally, production will also increase.

In conclusion the cost concept analysis showed that the barley production was profitable even in solar irrigated condition. Net return of the farmer after including irrigation charges was ₹ 25,644.35per ha. Regression analyses shows that there was decreasing returns to scale but with a very small margin. It can be improved by the 
optimal utilisation of all inputs that are underutilised or over utilized.

\section{References}

Directorate OF Millets Development. (2020). National Scenario of Coarse cereals.Department of Agriculture, Cooperation \& Farmers Welfare, Ministry of Agriculture \& Farmers Welfare, Government of Indiahttp://millets.dacfw.nic.in/India_Ap y.html

Directorate OF Millets Development. (2020). National Scenario of Coarse cereals.Department of Agriculture, Cooperation \& Farmers Welfare, Ministry of Agriculture \& Farmers Welfare, Government of Indiahttp://millets.dacfw.nic.in/PDF/Stat e-wise \&Crop-wise_APY_CC.pdf

Fthenakis, V., Mason, J. E., and Zweibel, K. (2009). The technical, geographical, and economic feasibility for solar energy to supply the energy needs of the US. Energy policy, 37(2), 387-399.

Gautam, Y. and Singh, O. P. (2020). Analysis of costs and resource productivity in pearl millet production under solar irrigation system in Jaipur, Rajasthan, Journal of Pharmacognosy and Phytochemistry, 9(6), 470-472

Gautam, Y. and Singh, O. P. (2020). Profitability And Resource Utilization In Groundnut Production Under Solar Irrigation System, International Journal of Current Microbiology and Applied Sciences, 9(10), 1993-1999

Government of India. (2019). Agricultural statistics at a glance. Directorate of Economics and Statistics. Dept. of Agric. and Co-operation. Ministry of Agriculture, Government of India.

Yash, G., \& Singh, P. K. (2018). Economic analysis of sorghum in Maharashtra, India. International Journal of
Agricultural and Statistical

Sciences, 14(2), 601-606.

Klynveld Peat Marwick Goerdeler, (2014). Feasibility analysis for solar agricultural water pumps in India. Netherlands.

Meena R. S., Sharma D. and Rathore R. (2014). The most promising solar hot spots in India development and policy: the Thar desert of Rajasthan. International Journal of Engineering Development and Research. 3(1). 74-79

Ministry of Environment, Forest and Climate Change. (2016). Report of Indian network for climate change assessment. Government of India.

Ministry of Power. (2020).Power sector at a glance all India; 2016. Government of India.

https://powermin.nic.in/content/powersector-glance-all-india

Schock, R. N., Sims, R. E. H., Adegbululgbe, A., Fenhann, J., Konstantinaviciute, I., Moomaw, W., Nimir, H. B., Schlamadinger, B., Torres-Martínez, J., Turner, C., Uchiyama, Y., Vuori, S., Wamukonya, N. and Zhang, X. (2007). Energy supply. In Climate Change 2007: Mitigation. Contribution of Working Group III to the Fourth Assessment Report of the Intergovernmental Panel on Climate Change.Metz, B.; Davidson, O.R.; Bosch, P.R.; Dave, R.; Meyer, L.A. (eds). (pp. 252-322). Cambridge University Press.

Singal, S. K. (2007). Review of augmentation of energy needs using renewable energy sources in India. Renewable and sustainable energy reviews, 11(7), 16071615.

World Health Organization. Exposure to ambient air pollution; 2017. Retrieved from:

〈http://www.who.int/gho/phe/outdoor_air _pollution/exposure/en/>. [Accessed on 5 August 2020] 


\section{How to cite this article:}

Yash Gautam and O. P. Singh and Singh, P. K. 2021. Economic Analysis of Barley Production under Solar Irrigation System in Jaipur, Rajasthan. Int.J.Curr.Microbiol.App.Sci. 10(01): 20302037. doi: https://doi.org/10.20546/ijcmas.2021.1001.234 